\title{
Biochemical changes in the cervical mucus of buffalo after induction of oestrus with prostaglandin F-2 $\alpha$ and cloprostenol*
}

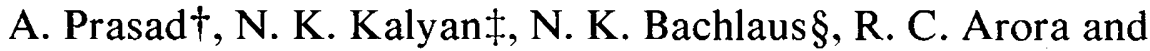 \\ R. S. Pandey \\ Biochemistry Section, Dairy Chemistry Division, National Dairy Research Institute, \\ Karnal 132001, India
}

\begin{abstract}
Summary. Prostaglandin F-2 $\alpha$ and cloprostenol were given as an i.m. injection on Days 9 or 15 of the cycle. There was a significant decline $(P<0.01)$ in the concentration of protein and activities of acid and alkaline phosphatase and peroxidase in cervical mucus after treatments, and the change was more marked in animals that responded by becoming oestrous within 4 days of treatment. Values in control animals remained steady or increased.
\end{abstract}

\section{Introduction}

Certain changes in the physical properties of the cervical mucus are essential for the passage of spermatozoa at the time of ovulation. These changes are under hormonal control: oestrogens cause mucus to be thin and clear whereas progestational agents render it thick, opaque, viscid and impenetrable to spermatozoa (Abarbarel, 1946). The biochemistry underlying these physical changes is not clear but it is possible that quantitative alterations in the glycoproteins and other cellular protein fractions are involved. Protein analysis of cervical mucus has been used to assess cervical function in relation to sex hormones and sperm penetration (Elstein \& MacDonald, 1970). Wide variations in carbohydrate, protein and non-protein nitrogen contents have been observed in cervical mucus at different stages of the oestrous cycle in cows (Roychoudhary \& Razdan, 1965), and the alkaline phosphatase, total protein and non-protein nitrogen content of cervical mucus in cows and buffaloes at oestrus have been reported (Agarwal \& Datta, 1978; Agarwal, Pangavkar \& Datta, 1978). Cyclic changes in the chemical composition of cervical mucus in buffalo have been described (Prasad, Bachlaus, Arora \& Pandey, 1980) but there are no reports on the changes after induction of oestrus by administration of prostaglandin (PG) F-2 $\alpha$ or an analogue to induce regression of the corpus luteum (Jainudeen, 1976; Bachlaus, Arora, Prasad \& Pandey, 1979; Pandey, 1979). We have therefore studied the biochemical composition of buffalo cervical mucus after induction of oestrus.

\section{Animals}

\section{Materials and Methods}

The experimental animals consisted of 54 buffalo heifers (Murrah type) aged $2 \frac{1}{2}-3$ years (average body weight $200-250 \mathrm{~kg}$ ). They were maintained under normal feeding conditions at the Institute's cattle yard. The experiment was conducted over the period mid-September to

* Reprint requests to Dr R. S. Pandey.

+ Present address: Veterinary College, Ranchi, India.

$\ddagger$ Present address: Biochemistry Department, State University of New York at Buffalo, New York, U.S.A.

$\S$ Present address: Indian Standards Institution, Pune, India. 
mid-December during 1976. All animals had showed at least two periods of oestrus before the treatment which was given at Day 9 or 15 of the oestrous cycle (Day $0=$ day of oestrus).

\section{Treatment}

The animals were divided into 6 treatment groups as follows. Animals in Groups 1, 2 and 3 were treated on Day 9 by intramuscular injection of $2 \mathrm{ml}$ glass-distilled water (Group 1, controls, $\mathrm{N}=9$ ), $33.5 \mathrm{mg}$ PGF-2 $\alpha$ (THAM salt, equiv. to $25 \mathrm{mg}$ PGF-2 $\alpha$; Upjohn, Kalamazoo, Michigan, U.S.A.) in $2 \mathrm{ml}$ distilled water (Group 2, $\mathrm{N}=11$ ) or $500 \mu \mathrm{g}$ cloprostenol (Estrumate: ICI, Cheshire, U.K.) in $2 \mathrm{ml}$ distilled water (Group 3, $\mathrm{N}=9$ ). Animals in Groups $4(\mathrm{~N}=9$ ), 5 $(\mathrm{N}=7)$ and $6(\mathrm{~N}=9)$ were given the same treatments but on Day 15. A teaser bull was used twice a day for detection of oestrus. Animals exhibiting symptoms of oestrus within 4 days after the treatment were classified as 'responders' and the rest which returned to oestrus within 5-26 days, as 'non-responders'.

\section{Collection of cervical mucus}

Daily samples of cervical mucus were collected for 4 days after treatment by the method of Alliston, Patterson \& Ulberg (1958) with the slight modifications reported by Prasad et al. (1980). At the time of sampling, the ovaries of each animal were examined by rectal palpation to establish the changes in size of follicles and corpora lutea. Any samples of mucus tinged with blood or containing pus were rejected. All samples were stored at $-20^{\circ} \mathrm{C}$ until analysis which was completed within 1 month of collection.

\section{Analysis of protein and enzymes}

The samples were thawed at room temperature $\left(20-22^{\circ} \mathrm{C}\right)$. A known quantity $(100-200 \mathrm{mg})$ of the sample was dispersed thoroughly in saline $(9 \mathrm{~g} \mathrm{NaCl} / 1)$ at $8^{\circ} \mathrm{C}$ by vigorous vortexing for $5 \mathrm{~min}$ and the volume was made up to $5 \mathrm{ml}$. A $0.5 \mathrm{ml}$ aliquot of the sample was used for estimation of protein by the method of Lowry, Rosebrough, Farr \& Randall (1951). The activities of alkaline and acid phosphatase were assayed by the method of Bergmeyer (1963) using $p$-nitrophenyl phosphate (V. P. Chest Institute, Delhi) as substrate. Homogenized cervical mucus samples $(0.1 \mathrm{ml}$ for alkaline phosphatase and $0.2 \mathrm{ml}$ for acid phosphatase) were incubated with $1 \mathrm{ml} 0.05 \mathrm{M}$-glycine-sodium hydroxide buffer, $\mathrm{pH} 10.5$ (for alkaline phosphatase) or $1 \mathrm{ml} 0.05 \mathrm{M}$-citrate buffer, $\mathrm{pH} 4.8$ (for acid phosphatase) containing $5.5 \times 10^{-3} \mathrm{M}$ $p$-nitrophenyl phosphate at $37^{\circ} \mathrm{C}$ for $30 \mathrm{~min}$. The reaction was stopped by the addition of 10 ml $0.02 \mathrm{~N}-\mathrm{NaOH}$ or $4 \mathrm{ml} 0.1 \mathrm{~N}-\mathrm{NaOH}$ for alkaline or acid phosphatase respectively. The optical density of the liberated $p$-nitrophenol was read on a colorimeter. Unit activity of the enzyme was calculated as $\mu \mathrm{M} p$-nitrophenol liberated $/ \mathrm{h}$ per $\mathrm{g}$ cervical mucus at $37^{\circ} \mathrm{C}$.

The activity of peroxidase was also estimated by the method of Bergmeyer (1963) using 1\% $p$-phenylenediamine as substrate. The assay mixture consisted of $2.5 \mathrm{ml} 0.067 \mathrm{M}$-phosphate buffer, $\mathrm{pH} 7 \cdot 0,0 \cdot 1 \mathrm{ml}$ diluted hydrogen peroxide, $0.1 \mathrm{ml}$ of a sample of homogenized cervical mucus. The increase in optical density was recorded at $485 \mathrm{~nm}$. A unit of the enzyme was the amount of peroxidase which changed the optical density by $0.001 / \mathrm{sec}$. The activity was expressed in enzyme units/g cervical mucus.

\section{Statistical analyses}

All the values are expressed as means ( \pm s.e.m.) and the data were evaluated by analysis of variance (Snedecor \& Cochran, 1967) for differences between control and treated animals and between days after treatment within a group. 


\section{Results}

The occurrence of oestrus in the heifers is summarized in Table 1. The results of the assays for protein, acid and alkaline phosphatase and peroxidase are given in Text-fig. 1. For the control heifers there were no marked changes in protein and acid phosphatase activity, but the activity of alkaline phosphatase doubled between Days 9 and 18 and peroxidase activity rose 3-fold between Days 9 and 12. A single injection of PGF-2 $\alpha$ or cloprostenol on Days 9 or 15 resulted in responding heifers in a significant decline of protein concentration $(P<0.01$ for both) by Day 2 after treatment. The non-responders, which had poorly regressed CL as ascertained by rectal palpation, also showed an early decline but values then stayed intermediate between those of the controls and the responders. The changes of alkaline phosphatase were similar in pattern to those of protein for the responding and non-responding heifers and the falls in the responders were significant $(P<0.01)$ by Day 2 after treatment.

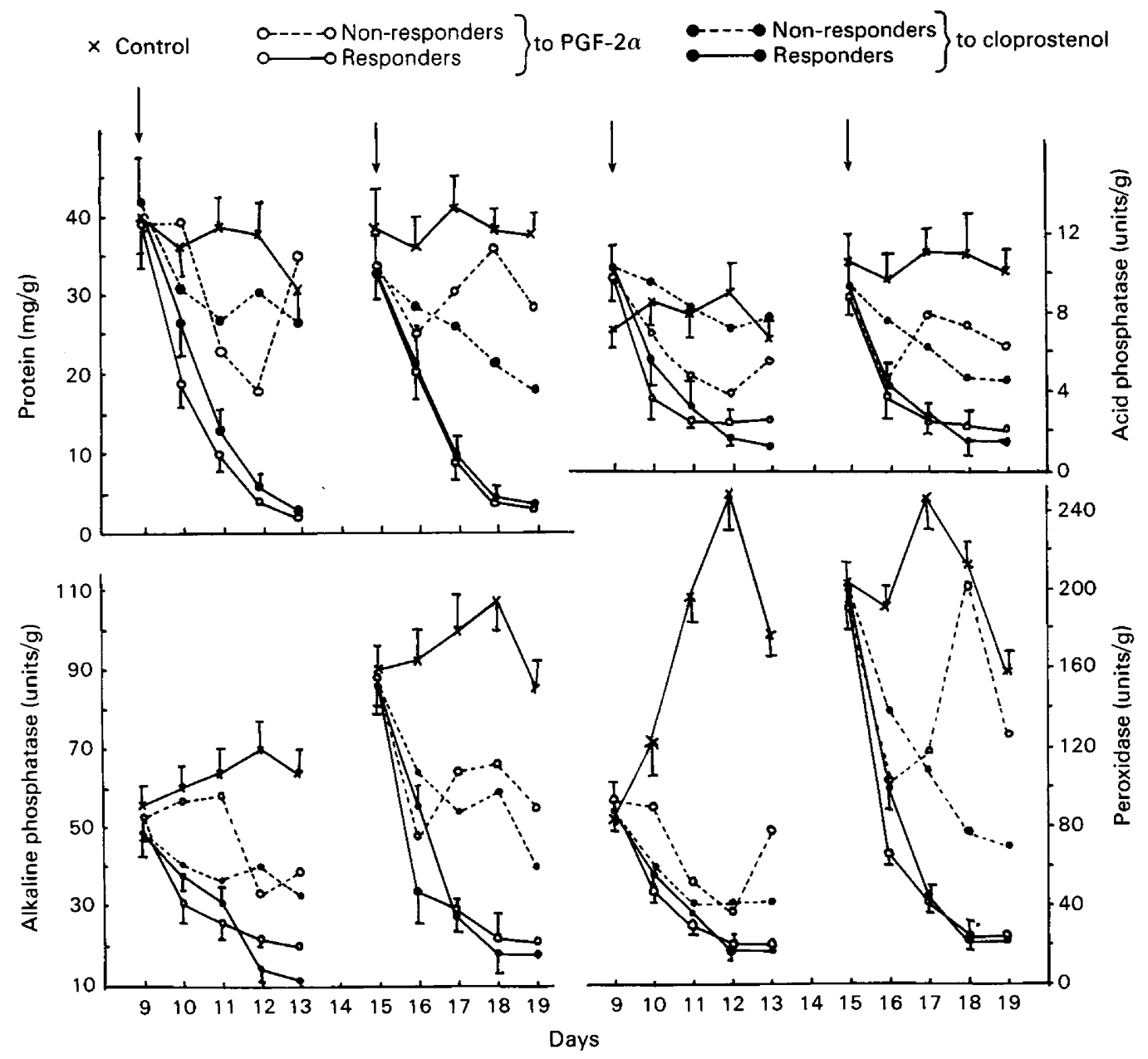

Text-fig. 1. Changes in the mean ( \pm s.e.m.) values of various constituents of the cervical mucus of buffalo heifers after treatment with PGF-2 $\alpha$ or cloprostenol (arrow) on Days 9 or 15 of the cycle. See Table 1 for the numbers of animals in each group. The s.e.m. values for the non-responders have been excluded since there were $<3$ animals in each group. 
Table 1. Occurrence of oestrus in buffalo heifers

\begin{tabular}{ccccccc}
\hline & \multirow{2}{*}{$\begin{array}{c}\text { No. of } \\
\text { Group }\end{array}$} & $\begin{array}{c}\text { No. of animals } \\
\text { animals }\end{array}$ & \multicolumn{2}{c}{ Distribution of oestrus response } & \\
\cline { 5 - 6 } & 11 & 8 & 2 & 5 & 1 & Non-responders \\
\hline 5 & 7 & 5 & 1 & 3 & 1 & 3 \\
3 & 9 & 8 & 1 & 4 & 3 & 1 \\
6 & 9 & 7 & 2 & 3 & 2 & 2 \\
\hline
\end{tabular}

* Within 4 days of treatment. The control animals in Groups $1(N=9)$ and $4(N=9)$ did not return to oestrus within 4 days.

The pattern of change for acid phosphatase activity was again a marked drop $(P<0.01)$ in the responding animals and less pronounced falls for the non-responders. All animals, responders and non-responders in Groups 2 and 3 showed reduced peroxidase activity $(P<0.01)$ but the fall was more marked for the responders in Groups 5 and 6.

\section{Discussion}

The results of the control animals were similar to those previously reported (Prasad et al., 1980). The reduced protein level of cervical mucus at oestrus is in agreement with the observations of Elstein \& Pollard (1968), Hamana, Elbama \& Hafez (1971) and Linford (1974). The differences between the responders and non-responders relates to the incomplete regression of the corpora lutea in the latter. Higher pretreatment activity of alkaline phosphatase is in agreement with the report of Vanlinkenberg (1953) and Smith, Hunter \& Spadoni (1970) in women undergoing treatment with progestational agents. The activity of alkaline phosphatase in cervical mucus has been reported to be consistently low under the influence of oestrogen and progestagen administration (Smith et al., 1970). Identical treatments of PGF-2 $\alpha$ and cloprostenol in buffaloes enhance plasma oestradiol-17 $\beta$ levels within $48-72 \mathrm{~h}$ after the injection (Bachlaus et al., 1979). It therefore appears that high,oestradiol levels exert some inhibitory effect on the secretion of phosphatases and other chemical constituents which probably accounts for their lower levels following induction of oestrus. Endometrial phosphatases have also been observed to increase during the proliferative phase but decrease in the secretory phase (Gregoire, Kandil \& Beyer, 1972). Peroxidase activity also decreases at oestrus after treatment with these hormones: Linford (1974) reported that the peroxidase content in the cervical mucus of cattle fluctuated throughout the cycle but dropped to a very low level before ovulation. It is apparent that the activity of peroxidase reflects the changing luteal activity following induced luteolysis in buffaloes. The decrease in peroxidase activity in cattle (Linford, 1974) and buffalo, however, is contrary to the results in other animals; e.g. treatment of immature female rats with oestrogens resulted in increased peroxidase activity in the uterus (Lyttle \& Jellinck, 1972; McNabb \& Jellinck, 1974).

The quantitative decreases in the various biochemical constituents in buffalo cervical mucus observed in the present investigation following induction of oestrus may not solely reflect the varying rates of secretion but could also be related to the changing degree of hydration under oestrogen dominance, which dilutes mucus components at oestrus. However, the administration of PGF-2 $\alpha$ and cloprostenol significantly alters the biochemical constituents of cervical mucus in this animal.

We thank Dr J. W. Lauderdale, Upjohn Company, U.S.A., and Dr M. J. Cooper, ICI, U.K., for the gifts of PGF-2 $\alpha$ and cloprostenol, respectively, and Mr D. K. Sadana for help with the statistical analyses. 


\section{References}

Abarbarel, R. (1946) Artificial reproduction of the cyclic changes in cervical mucus of human castrates. Endocrinology 39, 65-66, Abstr.

Agarwal, S.C. \& Datta, I.C. (1978) A study of certain carbohydrate components and alkaline phosphatase activity in cervical mucus of buffaloes at oestrus. Ind. J. exp. Biol. 16, 388-393.

Agarwal, S.C., Pangavkar, G.R. \& Datta, I.C. (1978) A comparative study of the total protein and nonprotein nitrogen level in estrual cervical mucus in different breeds of cows and buffalo. Ind. Vet. J. 55, 756-760.

Alliston, C.W., Patterson, T.S. \& Ulberg, L.C. (1958) Crystallization patterns of cervical mucus as related to oestrus in beef cattle. J. Anim. Sci. 77, 322-325.

Bachlaus, N.K., Arora, R., Prasad, A. \& Pandey, R.S. (1979) Synchronization of oestrus in buffalo heifers with prostaglandin F-2 $\alpha$, its effect on plasma estrogen and progesterone levels. In Advances in Reproduction and Regulation of Fertility, pp. 149153. Ed. G. P. Talwar. Elsevier/North Holland Biomedical Press, Amsterdam.

Bergmeyer, N.U. (1963) Methods of Enzymatic Analysis, 1st edn. Academic Press, New York.

Elstein, M. \& MacDonald, R.R. (1970) The relation of cervical mucus proteins to sperm penetrability. $J$. Obstet. Gynaec. Br. Commonw. 77, 1123-1126.

Elstein, M. \& Pollard, A.C. (1968) Proteins of cervical mucus. Nature, Lond. 219, 612-613.

Gregoire, A.T., Kandil, O. \& Beyer, G. (1972) The acid and alkaline phosphatase activity in human cervical mucus of females using either a coil or combined therapy. Fert. Steril. 23, 15-17.

Hamana, K., Elbama, A.A. \& Hafez, E.S.E. (1971) Sialic acid and some physico-chemical characteristics of bovine cervical mucus. Cornell. Vet. 61, 104-113.
Jainudeen, M.R. (1976) Induction of oestrus and ovulation in buffalo (Bubalus bubalis) using cloprostenol, a synthetic analogue of prostaglandin F-2a. Kajian Veterinar. 8, 40-42.

Linford, E. (1974) Cervical mucus: an agent or a barrier to conception? J. Reprod. Fert. 37, 239-250.

Lowry, O.H., Rosebrough, N.J., Farr, A.L. \& Randall, R.J. (1951) Protein measurement with the Folin phenol reagent. J. biol. Chem. 193, 265-275.

Lyttle, C.R. \& Jellinck, P.H. (1972) Estrogen induced metabolism of oestradiol-17 $\beta$ in rat uterus. Possible mechanism for termination of oestrogen action. Steroids 20, 89-94.

McNabb, T. \& Jellinck, P.H. (1974) Origin of oestrogen induced uterine peroxidase. J. Endocr. 62, 415-416.

Pandey, R.S. (1979) Hormonal status of female and induced breeding in Murrah buffaloes. In Buffalo Reproduction and Artificial Insemination, pp. 185 210. FAO Animal Production and Health Paper 13, Food and Agriculture Organization of the United Nations, Rome.

Prasad, A., Bachlaus, N.K., Arora, R.C. \& Pandey, R.S. (1980) Protein concentration, phosphatases and peroxidase in cervical mucus of buffalo heifers during oestrous cycle. Ind. J. exp. Biol. 18, 251-253.

Roychoudhary, P.N. \& Razdan, M.N. (1965) Studies on some chemical constituents of cervical mucus of cattle. Ind. Vet. J. 42, 502-506.

Smith, D.C., Hunter, W.B. \& Spadoni, L.R. (1970) Alkaline phosphatase concentration in cervical mucus of cattle. Fert. Steril. 21, 549-554.

Snedecor, G.W. \& Cochran, W.G. (1967) Statistical Methods, Sixth edn. Oxford and IBH Publishing Company, New Delhi.

Vanlinkenberg, G.A. (1953) Extremely high alkaline phosphatase activity in vaginal mucus of cow. Nature, Lond. 172, 397-398. 